DINIZ, ER; VARGAS, TO; PEREIRA, WD; SANTOS, RHS; URQUIAGA, S; MODOLO, AJ. 2017. Levels of Crotalaria juncea on growth, production, recovery and efficiency of the use of $\mathrm{N}$ in broccoli. Horticultura Brasileira 35: 395-401. DOI - http://dx.doi.org/10.1590/S0102-053620170313

\title{
Levels of Crotalaria juncea on growth, production, recovery and efficiency of the use of $\mathbf{N}$ in broccoli
}

\author{
Ellen R Diniz'; Thiago O Vargas²; Wander D Pereira ${ }^{3}$; Ricardo HS Santos ${ }^{3}$; Segundo Urquiaga ${ }^{4}$; Alcir J \\ Modolo ${ }^{2}$
}

${ }^{1}$ Instituto Federal do Paraná (IFPR), Ivaiporã-PR, Brasil; ellen.diniz@ifpr.edu.br; ${ }^{2}$ Universidade Tecnológica Federal do Paraná (UTFPR), Pato Branco-PR, Brasil; thiagovargas@utfpr.edu.br; alcir@utfpr.edu.br; ${ }^{3}$ Universidade Federal de Viçosa (UFV), Viçosa-MG, Brasil; wanderdp@yahoo.com.br; rsantos@ufv.br; ㅌEmbrapa Agrobiologia, Seropédica-RJ, Brasil; segundo.urquiaga@embrapa.br

\begin{abstract}
The recommendation for green manure (GM) in cropping systems still has little scientific support, with few studies addressing the effects of nutrient amounts from green manure on the growth and production of the crop. Our aim was to evaluate the effect of levels of Crotalaria juncea green manure on the growth, production, and efficiency of the use as well as the apparent recovery of $\mathrm{N}$ in broccoli crop. Seven treatments were established; the main with four doses of green manure: $0,3,6$, and $9 \mathrm{t} /$ ha on a dry matter (DM) basis, applied with $12 \mathrm{t} / \mathrm{ha}$ compost. The control treatments consisted of mineral fertilization, the treatment with $25 \mathrm{t} / \mathrm{ha}$ compost, and another as the absolute control. Comparatively, production under the absolute control was less than all other treatments with green manure doses and application of $12 \mathrm{t} / \mathrm{ha}$ compost. The production of plants grown with $25 \mathrm{t} / \mathrm{ha}$ compost was superior to that of plants grown with dose of $0 \mathrm{t} / \mathrm{ha}$ and similar to that obtained with $3 \mathrm{t} / \mathrm{ha}$; however, it was inferior to those produced with doses of 6 and $9 \mathrm{t} / \mathrm{ha}$ green manure. The highest percentage of $\mathrm{N}$ recovered $(\mathrm{REC} \mathrm{N})$ by the broccoli plants was observed close to a dose of $3 \mathrm{t} / \mathrm{ha}$ green manure, with a maximum point of $37.90 \%(2.8 \mathrm{t} / \mathrm{ha})$, while in larger doses of 6 and $9 \mathrm{t} /$ ha showed estimated values of $31.91 \%$ and $20.49 \%$, respectively. The physiological efficiency of the use of N (EFUN) showed an effect similar to apparent recovery of $\mathrm{N}$ (REC N), with higher EFUN from lowest to highest dose of green manure, that is, 3,6 , and $9 \mathrm{t} / \mathrm{ha}$, with estimated values of 70.41,62.45, and $26.02 \mathrm{~g} \mathrm{DM}$ per $\mathrm{g}$ of $\mathrm{N}$ uptake, respectively. The mass amounts of applied $C$. juncea influenced positively on the growth and productivity of broccoli. The lower mass of applied green manure increases the physiological efficiency of the use of $\mathrm{N}$ with more apparent recovery of the applied $\mathrm{N}$.
\end{abstract}

Keywords: Brassica oleracea var. italica, green manure, nitrogen.

\section{RESUMO}

Doses de Crotalaria juncea no crescimento, produção, recuperação e eficiência de uso de $\mathbf{N}$ em brócolis

A recomendação da adubação verde nos sistemas de cultivos ainda apresenta pouco suporte científico e poucos estudos abordam os efeitos de quantidades de nutrientes provenientes de adubos verdes sobre o crescimento e a produção das culturas. $\mathrm{O}$ objetivo do trabalho foi avaliar o efeito das doses do adubo verde Crotalaria juncea sobre o crescimento, produção e na eficiência do uso e da recuperação aparente do N na cultura do brócolis. Foram estabelecidos sete tratamentos, sendo os principais quatro doses de adubo verde: $0,3,6$ e 9 t/ha em base de matéria seca, aplicadas junto com $12 \mathrm{t} / \mathrm{ha}$ de composto. Os tratamentos testemunhas consistiram de adubação mineral, um tratamento com $25 \mathrm{t} / \mathrm{ha}$ de composto e um outro como testemunha absoluta. A produção na testemunha absoluta foi inferior a todos os tratamentos com doses de adubo verde e aplicação de 12 $\mathrm{t} / \mathrm{ha}$ de composto. A produção das plantas produzidas com $25 \mathrm{t} / \mathrm{ha}$ de composto foi superior à produção das plantas produzidas com a dose 0 t/ha e similar à obtida com $3 \mathrm{t} / \mathrm{ha}$, entretanto foi inferior às produzidas com as doses 6 e 9 t/ha de adubo verde. O maior percentual de $\mathrm{N}$ recuperado pelas plantas de brócolis foi observado próximo a dose de $3 \mathrm{t} /$ ha de adubo verde, apresentando um ponto de máximo de 37,90\% (2,8 t/ha), ao passo que nas maiores doses, 6 e $9 \mathrm{t} / \mathrm{ha}$, apresentou valores estimados de 31,91 e 20,49\%, respectivamente. A eficiência fisiológica do uso do N (EFUN) apresentou efeito similar à recuperação aparente do $\mathrm{N}(\mathrm{REC} \mathrm{N})$, apresentando maior EFUN da menor à maior dose de adubo verde, 3,6 e 9 t/ha, com valores estimados de 70,41, 62,45 e 26,02 g de MS por g de $\mathrm{N}$ acumulado, respectivamente. As quantidades de massa de Crotalaria juncea aplicadas influenciaram positivamente o crescimento e a produtividade do brócolis. A menor massa aplicada de adubo verde eleva a eficiência fisiológica do uso do $\mathrm{N}$ com maior recuperação aparente do $\mathrm{N}$ aplicado.

Palavras-chave: Brassica oleracea var. italica, adubação verde, nitrogênio.

\section{Received on June 25, 2015; accepted on December 8, 2016}

A lthough there are studies on nutrition and fertilizer recommendations for the commercial cultivation of broccoli (Brassica oleracea var. italica) and works with other types of organic fertilizers such as compost or manure (Oliveira et al., 2003; Yuri et al., 2004; Damato Junior et al., 2005), there are few studies on the effects of green manure on the growth and production of broccoli. The literature also lacks studies relating green manure doses to the production and/or growth of horticultural products.

One of the few studies reports the influence of doses of organic compost
(OC) on yield and quality of the "Ramoso Santana" broccoli seeds. Four compost rates $(0,30,60,90$, and $120 \mathrm{t} / \mathrm{ha})$ with $0.72 \%$ nitrogen and $40 \%$ organic matter were applied. The production of broccoli seeds (number and weight) per plant increased linearly with increased doses of OC (Magro et al., 2010). 
The availability of $\mathrm{N}$ to plants differs when soluble mineral fertilizers as well as other fertilizers derived from organic sources are used.

Related to organic fertilizers, green manures, organic composts (OCs), manure, agro-industrial origin of waste such as castor cake, straw, and bagasse (Silva, 2008) all show wide variations in concentration of nutrients and various chemical constitutions, which influence the availability of nutrients.

Green manure with legumes results in slower $\mathrm{N}$ mineralization compared to mineral fertilizers (Perin et al., 2010). Nitrogen mineralization of the green manure is affected by biological processes of the soil, climate and soil conditions, species, and chemical and biochemical characteristics of the material. Working on twelve species, varieties, and different parts of green manure plants, Cobo et al. (2002) found that plants of the same species may have different nutrient concentrations, which directly influence the rates of decomposition.

The organic residues composting process is a directed model of organic matter humification process (Canellas \& Rumjanek, 2005). From the total amount of $\mathrm{N}$ in OCs produced using animal manure, $50 \%$ would be readily available to the plants, while in OCs produced using fish scraps obtained from shop, $15 \%$ of the total $\mathrm{N}$ would be available to the plants (Brinton Junior \& Seekins, 1994). Besides the immediate releases of nutrients for crops, OC promotes residual effect in the soil, benefiting subsequent crops (Araújo Neto et al., 2010).

Regardless of the source added to the soil, $\mathrm{N}$ needs to be mineralized in order to get absorbed by the crop. According to Araújo et al. (2005), using the $\mathrm{N}$ derived from green manure, that is, ${ }^{15} \mathrm{~N}$-sunn hemp and ${ }^{15} \mathrm{~N}$-urea for wheat, the recovery of $\mathrm{N}$ in the soil derived from urea applied in conjunction with sunn hemp was higher when compared to the application of ${ }^{15} \mathrm{~N}$-urea. Wheat required ${ }^{15} \mathrm{~N}$-urea as the main source of $\mathrm{N}$, indicating that the availability of $\mathrm{N}$ was abundant in this form in the soil. However, the percentage of recovery of $\mathrm{N}$ derived from urea or sunn hemp could be modified with applied dose modifications of the green manure.

The recommendation of green manure in cropping systems still has little scientific support, with few studies addressing the effects of nutrient amounts from green manure on the growth and production of the crop. The evaluation of the plant growth is a critical aspect to characterize the performance of the crop produced with different doses of green manure. The objective of the study was to evaluate the effect of levels of Crotalaria juncea green manure on the growth, production, and efficiency as well as the apparent use of $\mathrm{N}$ recovery in broccoli crop.

\section{MATERIAL AND METHODS}

The study was conducted in the Agroecology area of the Department of Plant Science, Universidade Federal de Viçosa, in Viçosa, Minas Gerais State (2046'09'S, 42 52'20"W, 650 $m$ altitude). The region has cold and dry winter as well as hot and rainy summer, with an average temperature of $19.4^{\circ} \mathrm{C}$ (max. $26.4^{\circ} \mathrm{C}$ and $\min .14 .8^{\circ} \mathrm{C}$ ) and average rainfall of $1.221 \mathrm{~mm} /$ year.

Seven treatments were established: four major treatments and three controls. The major treatments consisted of four doses of green manure (GM): $0,3,6$, and $9 \mathrm{t} / \mathrm{ha}$ on a dry matter (DM) basis, with addition of $12 \mathrm{t} / \mathrm{ha}$ of $\mathrm{OC}$ on a $\mathrm{DM}$ basis $(0 \mathrm{GM}+12 \mathrm{OC}, 3 \mathrm{GM}+12 \mathrm{OC}$, $6 \mathrm{GM}+12 \mathrm{OC}, 9 \mathrm{GM}+12 \mathrm{OC})$, according to Diniz et al. (2008). The control treatments consisted of a treatment with mineral fertilization (MF), $150 \mathrm{~kg} / \mathrm{ha}$ of $\mathrm{N}$ (ammonium nitrate), $400 \mathrm{~kg} / \mathrm{ha}$ of $\mathrm{P}_{2} \mathrm{O}_{5}$ (single superphosphate) and 100 $\mathrm{kg} / \mathrm{ha}$ of $\mathrm{K}_{2} \mathrm{O}$ (potassium chloride); a treatment with $25 \mathrm{t} / \mathrm{ha}$ compost on a DM basis (25OC), according to Diniz et al. (2008), and another treatment as absolute control without OC or mineral fertilizer (MF). The experimental plot consisted of five rows spaced $0.8 \mathrm{~m}$ with $3 \mathrm{~m}$ in length.

Chemical analysis of the soil (0-20 $\mathrm{cm}$ ) of the experimental area at the beginning of the test resulted in the following characteristics: $24 \mathrm{~g} / \mathrm{kg}$ of organic matter (Walkley-Black), $\mathrm{pH}$ in water $(1: 2.5)=6.5 ; 7.0 \mathrm{mg} / \mathrm{dm}^{3}$ of $\mathrm{P}$ (Mehlich I); $96 \mathrm{mg} / \mathrm{dm}^{3}$ of K (Mehlich I), $2.70 \mathrm{cmolc} / \mathrm{dm}^{3}$ of Ca, $0.40 \mathrm{cmolc} / \mathrm{dm}^{3}$ of $\mathrm{Mg}$, and $0.00 \mathrm{cmolc} / \mathrm{dm}^{3}$ of $\mathrm{Al}(\mathrm{KCl}$ $1 \mathrm{M})$.

The OC was produced on-site and applied to the planting furrows once before transplanting broccoli. Chemical analysis of the OC resulted: $1.73 \% \mathrm{~N}, 0.83 \% \mathrm{P}, 0.40 \% \mathrm{~K}, 2.12 \% \mathrm{Ca}$, $0.35 \% \mathrm{Mg}, 0.63 \% \mathrm{~S}$ and $\mathrm{C} / \mathrm{N}=10.63$. According to Tedesco et al. (1995), the total contents were determined in the acid extract and total carbon was calculated from the total content of organic matter determined by the loss of ignition method.

The green manure applied was the legume $C$. juncea (sunn hemp), which was produced in the field and harvested 70 days after planting. Legumes were planted with seed inoculation with appropriate strain of Bradyrhizobium spp. The green manure was cut at ground level, placed on a canvas, and dried in a greenhouse for two weeks. Next, the green manure was chopped into pieces of $30 \mathrm{~cm}$ and placed in raffia bags and stored in a closed shed, until the beginning of the experiment. The green manure was applied in the parts after transplanting the broccoli, without incorporation.

Upon cutting, the green manure samples on the same stalk:sheet ratio found in the field were removed and dried in a forced-air oven at $70^{\circ} \mathrm{C}$ until constant mass. The biochemical composition of sunn hemp had average contents of $\mathrm{N}=1.89 \%$, polyphenols $=$ $1.56 \%$, lignin $=11.89 \%$, cellulose $=$ $39.39 \%, \mathrm{C} / \mathrm{N}=26.55, \mathrm{Lig} / \mathrm{N}=6.29, \mathrm{Pol} /$ $\mathrm{N}=0.84$, and $\mathrm{Lig} / \mathrm{Pol}=7.62$. Based on the methodology proposed by Tedesco et al. (1995), the total $\mathrm{N}$ content was determined. The total carbon was calculated from the total content of organic matter determined by the loss of ignition method. The polyphenols were extracted with $50 \%$ methanol and determined colorimetrically using FolinDenis reagent (Frighetto \& Valarini, 2000). The contents of cellulose and lignin were obtained via acid detergent fiber from the plant material by boiling sulfuric acid solution of $0.5 \mathrm{~mol} / \mathrm{L}$ plus cetyltrimethylammonium bromide. 
The total amount of green N-manure applied in treatments was $0,56.7,113.4$, and $170.1 \mathrm{~kg} / \mathrm{ha}$ of $\mathrm{N}$ in doses of 0,3 , 6 , and $9 \mathrm{t} / \mathrm{ha}$, respectively, which were added to $207.6 \mathrm{~kg} / \mathrm{ha}$ of $\mathrm{N}$ related to the dose of $12 \mathrm{t} /$ ha of OC. About $0,432.5$, and $150 \mathrm{~kg} / \mathrm{ha}$ of $\mathrm{N}$ were added to the treatments of absolute control, with $25 \mathrm{t} / \mathrm{ha}$ of $\mathrm{OC}$, and mineral fertilizer, respectively.

Single-headed hybrid broccoli called the "Taurus" was transplanted soon after the application of the compost. The seedlings were transplanted to the field on March 26, 2010, with spacing of $80 \mathrm{~cm}$ between rows and $50 \mathrm{~cm}$ between plants. The broccoli growth was evaluated by mass accumulation of DM of shoot parts over the cycle until harvest. One plant per plot was sampled every 15 days. The plants were dried placing in a forced air circulation oven at $70^{\circ} \mathrm{C}$ until constant mass, followed by weighing. The relative growth rate (RGR) and the absolute growth rate (AGR) of the broccoli were calculated according to Benincasa (1988).

The RGR was calculated by the following equation:

$\operatorname{RGR}(\mathrm{g} / \mathrm{g} / 10$ days $)=\left[\left(\ln _{2}-\ln \mathrm{M}_{1}\right) /\left(t_{2}-t_{1}\right)\right]$

where RGR (g/g/10 days) = relative growth rate; $\ln \mathrm{M}_{2}=$ neperian logarithm of the mass in grams of the plant in the second sample; $\ln M_{1}=$ neperian logarithm of the mass in grams of the plant in the first sampling (previous sampling); $t_{2}$ and $t_{1}=10$ days between two samples.

The AGR was calculated by the following equation:

$$
\operatorname{AGR}(\mathrm{g} / 10 \text { days })=\left[\left(\mathrm{M}_{2}-\mathrm{M}_{1}\right) /\left(t_{2}-t_{1}\right)\right]
$$

where AGR (g/10 days) = absolute growth rate; $M_{2}=$ mass in grams of the plant in the second sample; $M_{1}=$ mass in grams of the plant in the first sampling (previous sampling); $t_{2}$ and $t_{1}=10$ days between two samples.

The production of broccoli was evaluated by fresh weight of the harvested inflorescence with $1.5 \mathrm{~cm}$ of flower stalk.

The amount of $\mathrm{N}$ accumulated in the plant (extracted amount) and the amount of $\mathrm{N}$ accumulated by the inflorescence of broccoli (quantity exported) were calculated from the relationship between the $\mathrm{N}$ content and the mass of bodies in relation to the plant. Thus, the amount of $\mathrm{N}$ accumulated in the plant and in the inflorescence of the produced broccoli was estimated.

The apparent recovery of $\mathrm{N}$ (REC $\mathrm{N}$ ) from green manure by broccoli plants was calculated by discounting the contribution of $12 \mathrm{t} /$ ha of the provided OC (12OC and 0GM), resulting in the following equation:

$\operatorname{REC} N(\%)=\{[\operatorname{Next}(G M)-\operatorname{Next}(A B)]$ / Applied N Qty (GM - 12OC) $\}-\{[$ Next (12OC) - Next (AB)] / Applied N Qty (12OC) $\} \times 100$

where $\operatorname{REC~N}(\%)=$ apparent recovery of $\mathrm{N}$ from doses of green manure by broccoli plants; Next (GM) $=$ Quantity of $\mathrm{N}$ extracted in $\mathrm{kg} / \mathrm{ha}$ by the mass of plants grown in each green manure dose; Next (12OC) = Quantity of $\mathrm{N}$ extracted in $\mathrm{kg} / \mathrm{ha}$ in broccoli plants grown with $0 \mathrm{t} / \mathrm{ha} \mathrm{GM}+12 \mathrm{t} / \mathrm{ha} \mathrm{OC}$; $\operatorname{Next}(\mathrm{AB})=$ Quantity of $\mathrm{N}$ extracted in $\mathrm{kg} / \mathrm{ha}$ of broccoli plants with absolute control, Quantity of applied N (GM); $(12 \mathrm{OC})=$ Quantity of $\mathrm{N}$ applied in $\mathrm{kg} /$ ha of green manure doses, $0 \mathrm{t} / \mathrm{ha} \mathrm{GM}$ $+12 \mathrm{t} /$ ha OC.

The efficiency of the use of $\mathrm{N}$ (EFUN) derived from green manure by broccoli plants was calculated by discounting the contribution of $12 \mathrm{t} / \mathrm{ha}$ of the provided OC (12OC and 0GM), resulting in the following equation [adapted from Fageria (1998)]:

$$
\text { EFUN }(g / g)=X-Y
$$

where

$$
\begin{gathered}
\mathrm{X}=[\mathrm{DM}(\mathrm{GM})]-[\mathrm{DM}(\mathrm{AB})] / \\
\text { ANA }(\mathrm{GM}-12 \mathrm{OC})
\end{gathered}
$$

and

$$
\begin{gathered}
\mathrm{Y}=[\mathrm{DM}(12 \mathrm{OC})-\mathrm{DM}(\mathrm{AB})] / \\
\text { ANA }(12 \mathrm{OC}-\mathrm{AB})
\end{gathered}
$$

EFUN $(\mathrm{g} / \mathrm{g})=$ physiological efficiency of $\mathrm{N}$ usage derived from the green manure doses of broccoli plants; $\mathrm{DM}(\mathrm{GM})=$ dry matter production in grams, of plants grown on each green manure dose; DM (AB) = dry matter production in grams, of plants grown under absolute control; ANA (GM); (12OC); $(\mathrm{AB})=$ total amount of $\mathrm{N}$ accumulated in the broccoli plant in grams, of plants grown on green manure doses; 0 t/ha GM + 12 t/ha OC; absolute control.

The experimental design was a randomized complete block with four replications in a split plot in time scheme for the growth variables with adjustment of statistical models by the response surface methodology. Data were evaluated by analysis of variance using $F$ test; regression models were chosen based on the biological phenomenon under study and in the significance of the regression coefficient using the $t$ test $(p \leq 0.05)$. The analyses were performed on the System for Statistical Analyses and Genetics, SAEG version 9.1 (Funarbe, 2007).

\section{RESULTS AND DISCUSSION}

The DM accumulation from broccoli plants increases over the days after transplanting (DAT) and also with the increase of green fertilizer doses (Figure 1).

The largest RGR occurred in the first 10 days after transplanting the dose of $9 \mathrm{t} /$ ha (Table 1). The dose of $9 \mathrm{t} / \mathrm{ha}$ resulted in the highest RGRs associated with increased mass. Plants with higher RGRs have the ability to produce greater amount of mass in relation to the preexisting mass. Although the AGR is small in the first 10 days, in this period, the RGR is high because there is a great investment of the plant in active photosynthetic tissues that contribute to mass formation in the plant (Diniz et al., 2008).

As the plant grows, the formation capacity of new tissues per mass unit decreases with time. With increasing doses of green manure, the AGR increases. The higher the dose of green manure, the greater the mass gain of broccoli plants, which is verified by the AGR (Table 1).

There was an effective treatment on broccoli production. Production in 
absolute control was less than all the treatments with green manure doses, presenting a broccoli production of
$11.00 \mathrm{~g} / \mathrm{plant}$. The production of plants treated with $25 \mathrm{t} /$ ha of compost, 123.90 $\mathrm{g} / \mathrm{plant}$, was higher than the production

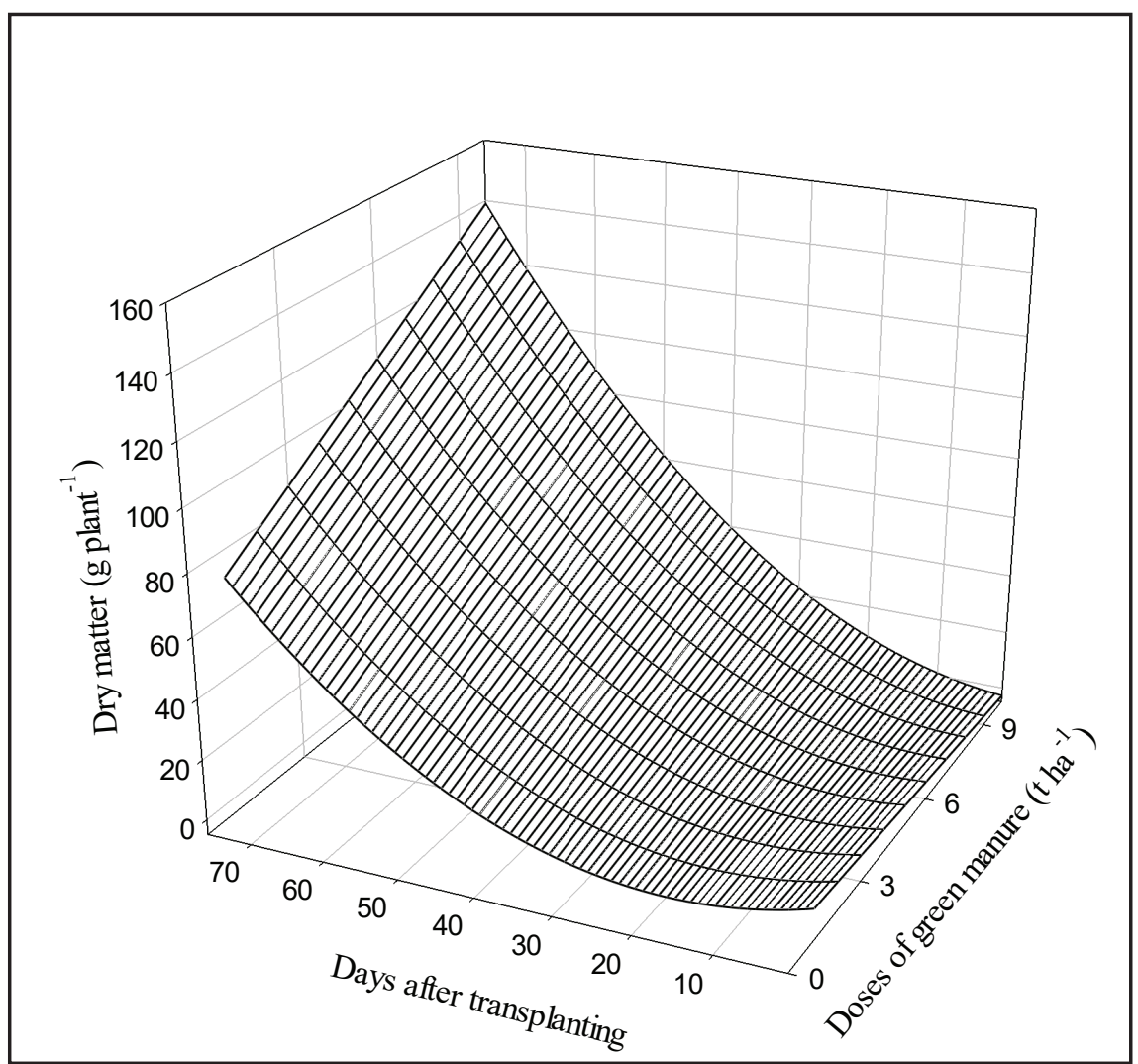

Figure 1. Effect of green manure doses (D) and days after transplanting (T) on the dry matter (DM) of broccoli plants. Viçosa, UFV, 2010.

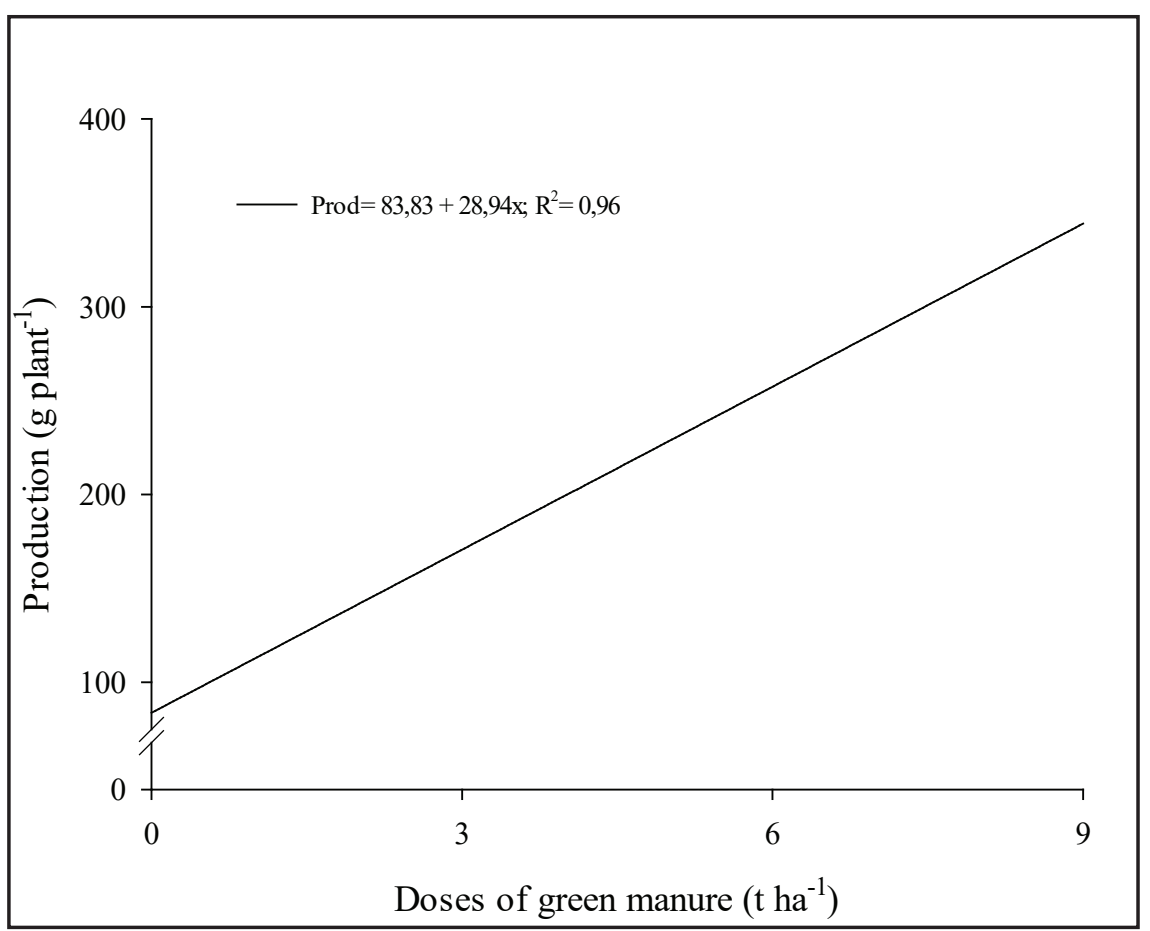

Figure 2. Broccoli production (Prod) depending on the doses of green manure, on DM basis. Viçosa, UFV, 2010. of plants treated with the dose of $0 \mathrm{t} / \mathrm{ha}$ green manure $+12 \mathrm{t} /$ ha compost, 102.01 $\mathrm{g} / \mathrm{plant}$, and was similar to that treated with $3 \mathrm{t} / \mathrm{ha}+12 \mathrm{t} /$ ha compost, 136.26, however, was lower than that treated with doses of 6 and $9 \mathrm{t} /$ ha green manure +12 t/ha compost, 271.70 and 346.26 $\mathrm{g} /$ plant, respectively.

The treatment with $25 \mathrm{t} /$ ha compost contained $432.5 \mathrm{~kg} / \mathrm{ha} \mathrm{N}$, and each green manure dose contained, beyond the green manure $\mathrm{N}$, over $207.6 \mathrm{~kg} /$ ha $\mathrm{N}$ via OC. Of the total $\mathrm{N}$ applied with the compost together with the mineralization using green manure, the amount of 287.0 and $326.7 \mathrm{~kg} / \mathrm{ha}$ of $\mathrm{N}$ was added at a dose of 6 and $9 \mathrm{t} / \mathrm{ha}$, respectively. Even with further $\mathrm{N}$ treatment with $25 \mathrm{t} / \mathrm{ha}$ of compost, the plants yielded less. Probably, the dynamics of mineralization and availability of $\mathrm{N}$ derived entirely from the $\mathrm{OC}$ are different from other treatments.

The slow decomposition of the manure, when compared to the green manure, was reported by Palm et al. (2001), where rapid decomposition of organic material has a short-term effect on soil fertility, while other materials have long-term effect. Although manure often adds further nutrients to the soil, it does not necessarily lead to increased availability of nutrients for the plants (Silva \& Menezes, 2007). In this study, the application of $25 \mathrm{t} /$ ha of $\mathrm{OC}$, despite further addition of nutrients to the soil, did not necessarily lead to the increased availability of nutrients for the plants in times of huge demand for the broccoli crop.

In a study conducted with the addition of manure (15 t/ha) or sunn hemp ( $3 \mathrm{t} / \mathrm{ha})$ or yet manure $(7,5 \mathrm{t} / \mathrm{ha})$ with sunn hemp (3 t/ha) incorporated for potato cultivation, the concentration of mineral $\mathrm{N}$ in soil, when applied only manure was lower than manure applied jointly with sunn hemp or separately (Silva \& Menezes, 2007). Sunn hemp increased the amount of mineral $\mathrm{N}$ in the soil in the initial period of the crops; however, the combination of sunn hemp with manure was more effective in providing nutrients throughout the potato cycle than the application of manure or sunn hemp alone.

Possibly, the high stabilization of 
the forms of the nutrients present in the $\mathrm{OC}$ reflects in its low availability in the soil and consequently in low doses of production compared to the plants receiving $9 \mathrm{t} / \mathrm{ha}$ green manure +12 t/ha OC.

There was an effect of green manure doses on the broccoli productivity (Figure 2). The production of broccoli increased linearly with the increase of green manure dose. Most of the broccoli production was $344.29 \mathrm{~g} / \mathrm{plant}$, equivalent to $7.65 \mathrm{t} / \mathrm{ha}$ of inflorescence fresh material. Into summer crops in notill system, this hybrid itself fertilized with $2 \mathrm{t} / \mathrm{ha}$ poultry litter $(60 \mathrm{~kg} / \mathrm{ha} \mathrm{N})$ plus $200 \mathrm{~kg} / \mathrm{ha}$ in mineral $\mathrm{N}$ form in coverage, produced $370.8 \mathrm{~g} /$ plant (Melo et al., 2010), yield similar to that found in this study, however with $\mathrm{N}$ as mineral source and amount greater than the $\mathrm{N}$ present in $9 \mathrm{t} / \mathrm{ha}$ green manure $+12 \mathrm{t} / \mathrm{ha}$ OC $(326.7 \mathrm{~kg} / \mathrm{ha})$.

Table 1. Relative growth rate (RGR) in $\mathrm{g} / \mathrm{g} / 10$ days and absolute growth rate (AGR) in $\mathrm{g} / 10$ days $g$ per plant, calculated from the dry matter of broccoli plants and measured every 10 days after transplanting to 70 days in broccoli plants grown with different green manure doses (0; 3; 6 and 9 t/ha). Viçosa, UFV, 2010.

\begin{tabular}{|c|c|c|c|c|c|c|c|c|}
\hline \multirow{2}{*}{$\begin{array}{l}\begin{array}{l}\text { Period } \\
\text { (days) }\end{array} \\
\end{array}$} & \multicolumn{2}{|c|}{$\mathbf{0}$} & \multicolumn{2}{|c|}{3} & \multicolumn{2}{|c|}{6} & \multicolumn{2}{|c|}{9} \\
\hline & RGR & AGR & RGR & AGR & RGR & AGR & RGR & AGR \\
\hline $0-10$ & 1.61 & 0.72 & 1.30 & 0.51 & 1.54 & 0.73 & 1.98 & 1.31 \\
\hline $10-20$ & 1.20 & 1.10 & 1.23 & 1.70 & 1.92 & 5.43 & 1.92 & 8.80 \\
\hline $20-30$ & 1.18 & 2.49 & 1.32 & 6.53 & 0.94 & 9.91 & 0.83 & 13.29 \\
\hline $30-40$ & 0.94 & 5.64 & 0.80 & 11.02 & 0.63 & 14.40 & 0.56 & 17.78 \\
\hline $40-50$ & 0.84 & 12.13 & 0.58 & 15.51 & 0.48 & 18.89 & 0.43 & 22.26 \\
\hline $50-60$ & 0.58 & 16.62 & 0.45 & 19.99 & 0.39 & 23.37 & 0.35 & 26.75 \\
\hline $60-70$ & 0.44 & 21.10 & 0.37 & 24.48 & 0.32 & 27.86 & 0.30 & 31.24 \\
\hline
\end{tabular}

plots (Fageria, 1998).

The highest percentage of recovered $\mathrm{N}$ by the broccoli plants was observed close to a dose of $3 \mathrm{t} / \mathrm{ha}$ green manure, with a maximum point of $37.90 \%(2.8 \mathrm{t} / \mathrm{ha})$, while the larger doses of 6 and $9 \mathrm{t} / \mathrm{ha}$ showed estimated values of $31.91 \%$ and $20.49 \%$, respectively. However, when the production was concerned, we found a linear increase with increasing doses of green manure (Figure 2).

The rapid mineralization of the green manure $\mathrm{N}$, corresponding to the application of $3 \mathrm{t} / \mathrm{ha}$ (Diniz et al., 2014), is possibly related to greater contact and distribution of the plant tissue with the ground, providing increased microbial activity (Meyer et al., 2011; Riutta et al., 2012).

The decomposition processes of the green manure and the mineralization of $\mathrm{N}$ may be directly related to the amount of mass factor, and therefore to the amount of applied N. It is important to consider beforehand that not all $\mathrm{N}$ applied via green manure will be available to crop (Diniz et al., 2007; Matos et al., 2008), even when applied in quantity greater than the recommended dose, especially in the case of short-cycle crop, such as vegetable products. A part of this green manure-N remains in the plant material until full mineralization.

Figure $3 \mathrm{~B}$ shows that the physiological efficiency of the use of $\mathrm{N}$ (EFUN) showed a similar effect to REC $\mathrm{N}$, with higher EFUN from lowest to highest dose of green manure, that is, 3 , 6 , and $9 \mathrm{t} / \mathrm{ha}$ and with estimated values

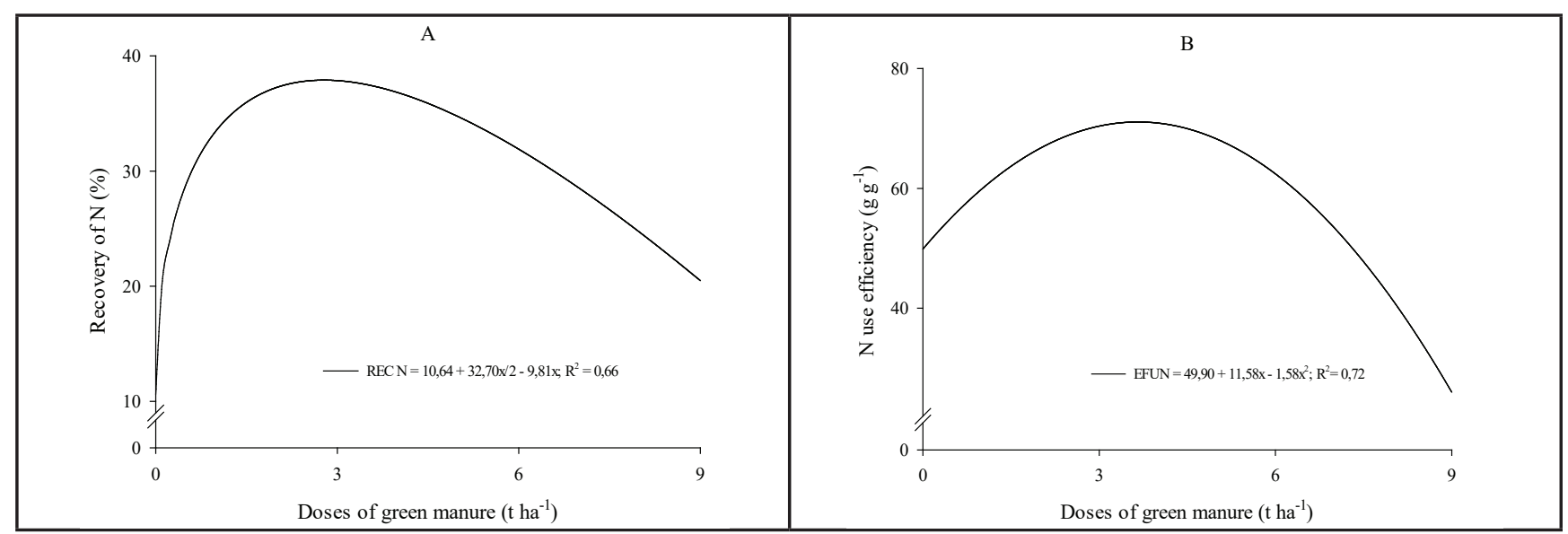

Figure 3. Apparent recovery of $\mathrm{N}(\mathrm{A}=\mathrm{REC} \mathrm{N})$ and $\mathrm{N}$ use efficiency $(\mathrm{B}=\mathrm{EFUN})$ of the broccoli plants in terms of doses of green manure, on DM basis. Viçosa, UFV, 2010. 
of $70.41,62.45$, and $26.02 \mathrm{~g} \mathrm{DM}$ per $\mathrm{g}$ of accrued $\mathrm{N}$, respectively. The maximum point occurred at a dose of $3.7 \mathrm{t} / \mathrm{ha}$ with efficiency of $71.1 \mathrm{~g} \mathrm{DM}$ per $\mathrm{g}$ of $\mathrm{N}$. The EFUN is the additional production of DM in the broccoli plots fertilized with respect to unfertilized plot, with additional $\mathrm{N}$ unit accumulated in plants of these plots (Fageria, 1998).

The lowest dose of green manure increases the EFUN with greater REC $\mathrm{N}$. In this sense, the broccoli plants took less of the nitrogen applied as green manure; in the highest doses of green manure, the plants were more efficient in producing DM of absorbed $\mathrm{N}$ per unit.

The main destination of fertilizer- $\mathrm{N}$ not absorbed by plants is the soil, where it remains trapped in the surface layer and is incorporated into the soil microbiota and then in its organic matter (Gava et al., 2006). However, the presence of N-biological fixation from subsequent green manure crops is small. The percentage of legume- $\mathrm{N}$ absorbed by crops varies from $12.45 \%$ to $22.9 \%$ of the total $\mathrm{N}$ derived from biological fixation (Castro et al., 2004; Silva et al., 2006; Diniz et al., 2007) and reaches about $20 \%$ of the total $\mathrm{N}$ applied as green manures (Scivittaro et al., 2000).

Despite the low apparent $\mathrm{N}$ recovery in plants grown under the effect of higher doses of green manure, the results point to the greater recovery of applied N (REC N) when compared to other studies.

The mass amounts of $C$. juncea influenced positively on the growth and productivity of broccoli. Broccoli plants took less amount of $\mathrm{N}$ applied as green manure. The lower mass of applied green manure increases the physiological efficiency of the use of $\mathrm{N}$ with more apparent recovery of the applied N.

\section{ACKNOWLEDGEMENTS}

The authors thank the Fundação de Amparo à Pesquisa do Estado de Minas Gerais (FAPEMIG) and the Conselho Nacional de Desenvolvimento Científico e Tecnológico (CNPq) for financial support.

\section{REFERENCES}

ARAÚJO, ASF; TEIXEIRA, GM; CAMPOS, AX; SILVA, FC; AMBROSANO, EJ; TRIVELIN, PCO. 2005. Utilização de nitrogênio pelo trigo cultivado em solo fertilizado com adubo verde (Crotalaria juncea) e/ou uréia. Ciência Rural 35: 284-289.

ARAÚJO NETO, SE; GALVÃO, RO; FERREIRA, RLF; PARMEJIANI, RS; NEGREIROS, JRS. 2010. Plantio direto de cebolinha sobre cobertura vegetal com efeito residual da aplicação de composto orgânico. Ciência Rural 40: 1206-1209.

BENINCASA, MMP. 1988. Análise de crescimento de plantas. Jaboticabal: FUNEP. 42p.

BRINTON JUNIOR, WF; SEEKINS, MD. 1994. Evaluation of farm plot conditions and effects of fish scrap compost on yield and mineral composition of field grown maize. Compost Science \& Utilization 2: 10-15.

CANELLAS, LP; RUMJANEK, VM. 2005. Espectroscopia na região do UltravioletaVisível. In: CANELLAS, LP; SANTOS, GA (eds). Humosfera: tratado preliminar sobre a química das substâncias húmicas. p.126-142.

CASTRO, MCD; ALVES, BJR; ALMEIDA, DJ; RIBEIRO, RLD. 2004. Adubação verde como fonte de nitrogênio para a cultura da berinjela em sistema orgânico. Pesquisa Agropecuária Brasileira 39: 779-785.

COBO, JG; BARRIOS, E; KASS, DCL; THOMAS, RJ. 2002. Decomposition and nutrient release by green manures in a tropical hillside agroecosystem. Plant and Soil 240: 331-342.

DAMATO JUNIOR, ER; LEONEL, S; PEDROSO, CJ. 2005. Adubação orgânica na produção e qualidade de frutos de maracujádoce. Revista Brasileira de Fruticultura 23: 188-190.

DINIZ, ER; SANTOS, RHS; URQUIAGA, SS; PETERNELLI, LA; BARRELLA, TP; FREITAS, GB. 2007. Green manure incorporation timing for organically grown broccoli. Pesquisa Agropecuária Brasileira 42: 199-206.

DINIZ, ER; SANTOS, RHS; URQUIAGA, S; PETERNELLI, LA; BARRELLA, TP; FREITAS, GB. 2008. Crescimento e produção de brócolis em sistema orgânico em função de doses de composto. Ciência e Agrotecnologia 32: $1428-1434$

DINIZ, ER; VARGAS, TO; PEREIRA, WD; GUEDES, AF; SANTOS, RHS; PETERNELLI, LA. 2014. Decomposição e mineralização do nitrogênio proveniente do adubo verde Crotalaria juncea. Científica 42: 51-59.

FAGERIA, NK. 1998. Otimização da eficiência nutricional na produção das culturas. Revista Brasileira de Engenharia Agrícola e Ambiental 2: 6-16.

FRIGHETTO, RTS; VALARINI, PJ. 2000. Indicadores biológicos e bioquímicos da qualidade do solo: manual técnico. Jaguariúna: Embrapa Meio Ambiente, 198p. (Embrapa Meio Ambiente. Documentos, 21).

FUNARBE. 2007. SAEG Sistema para análises estatísticas. Versão. 9.1. Viçosa-MG.

GAVA, GJC; TRIVELIN, PCO; OLIVEIRA, MW; HEINRICHS, R; SILVA, MA. 2006. Balanço do nitrogênio da uréia $(15 \mathrm{~N})$ no sistema soloplanta na implantação da semeadura direta na cultura do milho. Bragantia 65: 477-486.

MAGRO, FO; ARRUDA, N; CASA, J; SALATA, AC; CARDOSO, A; FERNANDES, DM. 2010. Composto orgânico na produção e qualidade de sementes de brócolis. Ciência e Agrotecnologia 34: 596-602.

MATOS, ES; MENDONÇA, ES; LIMA, PC; COELHO, MS; MATEUS, RF; CARDOSO, IM. 2008. Green manure in coffee systems in the region of Zona da Mata, Minas Gerais: characteristics and kinetics of carbon and nitrogen mineralization. Revista Brasileira de Ciência do Solo 32: 2027-2035.

MELO, RAC; MADEIRA, NR; PEIXOTO, JR. 2010. Cultivo de brócolos de inflorescência única no verão em plantio direto. Horticultura Brasileira 28: 23-28.

MEYER, WM; OSTERTAG, R; COWIE, RH. 2011. Macro-invertebrates accelerate litter decomposition and nutrient release in a Hawaiian rainforest. Soil Biology \& Biochemistry 43: 206-211.

OLIVEIRA, FL; RIBAS, RGT; JUNQUEIRA, RM; PADOVAN, MP; GUERRA, JGM; ALMEIDA, DL; RIBEIRO, RLD. 2003. Uso do pré-cultivo de Crotalária juncea e de doses crescentes de "cama" de aviário na produção do repolho sob manejo orgânico. Agronomia 37: 60-66.

PALM, CA; GILLER, KE; MAFONGOYA, PL; SWIFT, MJ. 2001. Management of organic matter in the tropics: translating theory into practice. Cycling Agroecosy 61: 63-75.

PERIN, A; SANTOS, RHS; CABALLERO, SSU; GUERRA, JGM; GUSMÃO, LA. 2010. Acúmulo e liberação de $\mathrm{P}, \mathrm{K}, \mathrm{Ca}$ e $\mathrm{Mg}$ em crotalária e milheto solteiros e consorciados. Revista Ceres 57: 274-281.

RIUTTA, T; SLADE, EM; BEBBER, DP; TAYLOR, ME; MALHI, Y; RIORDAN, P; MACDONALD, DW; MORECROFT, MD. 2012. Experimental evidence for the interacting effects of forest edge, moisture and soil macrofauna on leaf litter decomposition. Soil Biology \& Biochemistry 49: 124-131.

SCIVITTARO, WB; MURAOKA, T; BOARETTO, AE; TRIVELIN, PCO. 2000. Utilização de nitrogênio de adubos verde e mineral pelo milho. Revista Brasileira de Ciência do Solo 24: 917-926.

SILVA, EC; MURAOKA, T; BUZETTI, S; TRIVELIN, PCO. 2006. Manejo de nitrogênio no milho em Latossolo Vermelho sob plantio direto com diferentes plantas de cobertura. Pesquisa Agropecuária Brasileira 41: 477486.

SILVA, CA. 2008. Uso de resíduos orgânicos na 
agricultura In: SANTOS, GA; SILVA, LS; CANELLAS, LP; CAMARGO, FAO (eds).

Fundamentos da matéria orgânica do solo: ecossistemas tropicais e subtropicais. Porto Alegre: Metrópole. p. 597-624.

SILVA, TO; MENEZES, RSC. 2007. Adubação orgânica da batata com esterco e, ou, Crotalaria juncea: II - disponibilidade de N, P e K no solo ao longo do ciclo de cultivo. Revista Brasileira de Ciências do Solo 31: 51-61.

TEDESCO, MJ; GIANELLO, C; BISSANI, CA; BOHNEN, H; VOLKEISS, SJ. 1995. Análise de solo, plantas e outros materiais. Porto Alegre: UFRGS. 174p.

YURI, JE; RESENDE, GM; JUNIOR, R; MOTA, JH; SOUZA, RJ. 2004. Efeito de composto orgânico sobre a produção e características comerciais de alface americana. Horticultura Brasileira 22: 127-130. 